University of Nebraska - Lincoln

DigitalCommons@University of Nebraska - Lincoln

USDA National Wildlife Research Center - Staff Publications
U.S. Department of Agriculture: Animal and Plant Health Inspection Service

2020

\title{
Safety, Immunogenicity, and Efficacy of Intramuscular and Oral Delivery of ERA-G333 Recombinant Rabies Virus Vaccine to Big Brown Bats (Eptesicus fuscus)
}

\author{
Amy T. Gilbert \\ USDA National Wildlife Research Center, amy.t.gilbert@usda.gov \\ Xianfu Wu \\ Centers for Disease Control and Prevention \\ Felix R. Jackson \\ Centers for Disease Control and Prevention \\ Richard Franka \\ Centers for Disease Control and Prevention \\ GollgyFthifeerdaded itional works at: https://digitalcommons.unl.edu/icwdm_usdanwrc \\ ¿ikersity $q$ Thennessekesources and Conservation Commons, Natural Resources Management and \\ Policy Commons, Other Environmental Sciences Commons, Other Veterinary Medicine Commons,

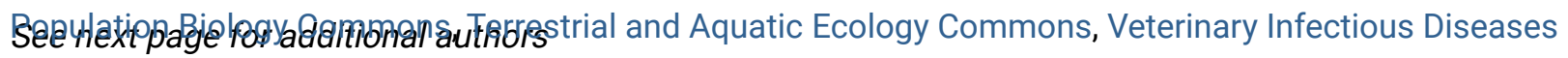 \\ Commons, Veterinary Microbiology and Immunobiology Commons, Veterinary Preventive Medicine, \\ Epidemiology, and Public Health Commons, and the Zoology Commons
}

Gilbert, Amy T.; Wu, Xianfu; Jackson, Felix R.; Franka, Richard; McCracken, Gary F.; and Rupprecht, Charles E., "Safety, Immunogenicity, and Efficacy of Intramuscular and Oral Delivery of ERA-G333 Recombinant Rabies Virus Vaccine to Big Brown Bats (Eptesicus fuscus)" (2020). USDA National Wildlife Research Center - Staff Publications. 2366.

https://digitalcommons.unl.edu/icwdm_usdanwrc/2366

This Article is brought to you for free and open access by the U.S. Department of Agriculture: Animal and Plant Health Inspection Service at DigitalCommons@University of Nebraska - Lincoln. It has been accepted for inclusion in USDA National Wildlife Research Center - Staff Publications by an authorized administrator of DigitalCommons@University of Nebraska - Lincoln. 


\section{Authors}

Amy T. Gilbert, Xianfu Wu, Felix R. Jackson, Richard Franka, Gary F. McCracken, and Charles E. Rupprecht 


\title{
SAFETY, IMMUNOGENICITY, AND EFFICACY OF INTRAMUSCULAR AND ORAL DELIVERY OF ERA-G333 RECOMBINANT RABIES VIRUS VACCINE TO BIG BROWN BATS (EPTESICUS FUSCUS)
}

\author{
Amy T. Gilbert, ${ }^{1,2,5}$ Xianfu Wu, ${ }^{1}$ Felix R. Jackson, ${ }^{1}$ Richard Franka, ${ }^{3}$ Gary F. McCracken, ${ }^{2}$ and \\ Charles E. Rupprecht ${ }^{4}$ \\ ${ }^{1}$ Poxvirus and Rabies Branch, Division of High-Consequence Pathogens and Pathology, Centers for Disease Control \\ and Prevention, 1600 Clifton Rd. NE, Atlanta, Georgia 30333, USA \\ ${ }^{2}$ Department of Ecology and Evolutionary Biology, University of Tennessee, 1416 Circle Dr., Knoxville, Tennessee \\ 37996, USA \\ ${ }^{3}$ Center for Global Health, Global Immunization Division, Centers for Disease Control and Prevention, 1600 Clifton Rd \\ NE, Atlanta, Georgia 30333, USA \\ ${ }^{4}$ LYSSA LLC, 309 Pirkle Ferry Rd., Suite D300, Cumming, Georgia 30040, USA \\ ${ }^{5}$ Corresponding author (email: amy.t.gilbert@usda.gov)
}

ABSTRACT: Attenuated strains of rabies virus (RABV) have been used for oral vaccination of wild carnivores in Europe and North America. However, some RABV vaccines caused clinical rabies in target animals. To improve the safety of attenuated RABV as an oral vaccine for field use, strategies using selection of escape mutants under monoclonal antibody neutralization pressure and reverse genetics-defined mutations have been used. We tested the safety, immunogenicity, and efficacy of one RABV construct, ERA-g333, developed with reverse genetics by intramuscular (IM) or oral (PO) routes in big brown bats (Eptesicus fuscus). Twenty-five bats received $5 \times 10^{6}$ mouse intracerebral median lethal doses $\left(\right.$ MICLD $_{50}$ ) of ERA-g333 by IM route, 10 received $5 \times 10^{6}$ MICLD $_{50}$ of ERA-g333 by PO route, and 22 bats served as unvaccinated controls. Twenty-one days after vaccination, 44 bats were infected by IM route with $10^{2.9}$ MICLD $_{50}$ of E. fuscus RABV. We report both the immunogenicity and efficacy of ERA-g333 delivered by the IM route; no induction of humoral immunity was detected in bats vaccinated by the PO route. Two subsets of bats vaccinated IM $(n=5)$ and PO $(n=3)$ were not challenged, and none developed clinical rabies from ERA-g333. Scarce reports exist on the evaluation of oral rabies vaccines in insectivorous bats, although the strategy evaluated here may be feasible for future application to these important RABV reservoirs.

Key words: Bat, Eptesicus fuscus, ERA, rabies, reverse genetics, vaccination.

\section{INTRODUCTION}

Rabies is a zoonotic disease caused by infection with negative-sense, single-stranded RNA viruses in the genus Lyssavirus. Rabies virus (RABV) is responsible for an estimated $>59,000$ human fatalities each year worldwide, the majority of which are transmitted through bites by rabid dogs (Hampson et al. 2015). In the Americas, bats are also an important RABV reservoir for human and animal infections (Messenger et al. 2002; Schneider et al. 2009). While the common vampire bat (Desmodus rotundus) is the most important RABV reservoir of human and animal infections in Latin America, insectivorous bat RABV is associated with the majority of human infections, as well as spillover and epizootic events in wild carni- vores in Canada and the US (Leslie et al. 2006; De Serres et al. 2008; Kuzmin et al. 2012). The highest diversity of sylvatic RABV reservoirs is found in the Americas, in part due to the independent circulation of RABV in multiple insectivorous bat species (Gilbert 2018). The most widely employed modern method for wildlife RABV control is a strategy of oral rabies vaccination (ORV; World Health Organization 2018). Because ORV efforts primarily target wild carnivore RABV reservoirs, few studies have evaluated oral rabies vaccines in bats.

The Evelyn-Rokitniki-Abelseth (ERA) strain of RABV is an attenuated virus that was derived from the Street-Alabama-Dufferin RABV strain. Both RABV strains have been used for ORV in carnivore reservoirs in North America and Europe (MacInnes et al. 2001; 
Muller et al. 2015), yet cases of residual pathogenicity have been reported after the field use in target and nontarget animals (Fehlner-Gardiner et al. 2008; Vuta et al. 2016). One study demonstrated that the pathogenicity of the ERA strain can be significantly altered by mutations at amino acid residue 333 of the glycoprotein (Dietzschold et al. 1983). Escape mutants of the Street-Alabama-Dufferin virus strain were produced under monoclonal antibody selection pressure at position 333 and identified as SAG1 and SAG2 (Le Blois et al. 1990; Lafay et al. 1994), the latter of which has also been widely used for ORV of wildlife in Europe (Mähl et al. 2014). Site-directed mutagenesis was also utilized to alter all three nucleotides at position 333 of the ERA glycoprotein gene (ERA-g333) to further improve the safety profile by reducing the chance for reversion to a virulent phenotype. Experimental studies have demonstrated the safety, immunogenicity, and efficacy of this construct for laboratory animal models and nonhuman primates, red foxes (Vulpes vulpes), gray foxes (Urocyon cinereoargenteus), and raccoon dogs (Nyctereutes procyonoides; Bankovskiy et al. 2008; Franka et al. 2009; Wu et al. 2011; Smith et al. 2017). A similar construct was also reported to be safe, immunogenic, and efficacious by intramuscular and oral delivery for domestic dogs (immunogenicity only) and raccoon dogs (Yang et al. 2014, 2015, 2016). No studies to our knowledge have examined ERA or its derivatives in bats.

The objective of this study was to evaluate experimentally the relative safety, immunogenicity, and efficacy of ERA-g333, delivered by the intramuscular (IM) and oral (PO) routes, against a lethal RABV infection in big brown bats (Eptesicus fuscus).

\section{MATERIALS AND METHODS}

\section{Animals and housing}

Experimental procedures and animal care were performed in compliance with the Centers for Disease Control and Prevention (CDC) Institutional Animal Care and Use Committee guidelines (protocol 1405RUPBATL). During June and
September 2007, 57 big brown bats were collected using butterfly nets from a building roost in Georgia, as authorized by Georgia Department of Natural Resources Scientific Collection permit 29-WCH-07-54. Bats were held captive in quarantine at the CDC for at least 1 mo prior to use and marked individually with metal bands on the forearm. During quarantine and acclimation, bats were trained to eat commercial live mealworms (Tenebrio molitor) from petri dishes. For the duration of the experiment, individual petri dishes of water and mealworms were offered ad libitum to each cage of bats and refreshed daily. Eleven groups of bats were housed separately in $813 \times 305 \times 254 \mathrm{~mm}$ stainless-steel cages, with all cages held in a room at 24-27 C and about $30 \%$ humidity. Two cages (N, $\mathrm{O})$ held groups of six bats, and the remaining nine cages ( $\mathrm{L}, \mathrm{M}, \mathrm{P}, \mathrm{Q}, \mathrm{R}, \mathrm{S}, \mathrm{T}, \mathrm{U}, \mathrm{V})$ held groups of five bats (see Supplementary Material Table S1). Baseline sera were collected to screen the RABV exposure status of bats prior to vaccination.

\section{Vaccination}

The ERA-g333 vaccine used for these experiments has been previously described (Bankovskiy et al. 2008). Bats were manually restrained and administered $5 \times 10^{6}$ focus-forming units (FFU) of ERA-g333 $\left(0.05 \mathrm{~mL}\right.$ of $\left.10^{8} \mathrm{FFU} / \mathrm{mL}\right)$ by IM $(n=25)$ or PO $(n=10)$ routes, replicated as two consecutive experiments. Unvaccinated control bats $(n=22)$ were not mock treated. The volume used was appropriate for our 15-20 g subjects (Stading et al. 2017). Vaccine treatments were assigned to replicate cages of bats. On day 0,25 bats were vaccinated by IM route in the deltoid muscle, and 10 bats were vaccinated by $\mathrm{PO}$ route using a needless syringe. The PO delivery of vaccine was made by depositing droplets into the open mouth of the manually restrained bat, allowing the bat time to swallow between droplets. Seventeen bats served as unvaccinated controls and were held in separate cages from vaccinated bats. Five bats served as unvaccinated and uninfected contact controls with orally vaccinated $(n=2$, cages $\mathrm{N}$ and $\mathrm{O})$ and unvaccinated control bats $(n=3$, cage $\mathrm{P})$ during experiment 1 . No contact controls were held during experiment 2.

Blood samples were obtained from a peripheral wing vein during each experiment or by the intracardiac route for terminal exsanguination under heavy anesthesia during euthanasia (Voigt and Cruz-Neto 2009), and these samples were collected in sterile heparinized microcapillary tubes. Serum was separated by low-speed centrifugation and stored at $-20 \mathrm{C}$ until processing. Bats were bled at similar intervals, including days 5, 14, 27, 43, 98, and 155 postvaccination (PV) 
during experiment 1 and days 5, 19, 34, 49, 90, and $161 \mathrm{PV}$ during experiment 2 .

\section{RABV challenge}

The E. fuscus RABV used for challenge was collected from the salivary glands of a naturally infected big brown bat in Pennsylvania during 2006 (PAEf3684; CDC accession no. A06-3684), as described previously (Turmelle et al. 2010). On day $21 \mathrm{PV}$, bats were restrained manually and inoculated by IM route into both the left and right masseter muscles with $10^{4.2}$ mouse intracerebral median lethal dose $\left(\right.$ MICLD $\left._{50}\right) / \mathrm{mL}$ of RABV in a volume of $0.05 \mathrm{~mL}$. Twenty-seven vaccinates were challenged across two experiments, including 20 bats vaccinated by IM and seven bats vaccinated by PO. In total, 17 unvaccinated bats were challenged as controls across two experiments. Animals were monitored daily for clinical signs of rabies for $140 \mathrm{~d}$ postinfection (PI).

Bats were subjected to exsanguination under heavy anesthesia and euthanized by intracardiac injection of a barbiturate solution (i.e., pentobarbital sodium and phenytoin sodium), upon presentation of two or more definitive clinical signs of RABV infection (e.g., increased aggression/reclusion, acute weight loss, ataxia, atypical vocalizations, paresis, or paralysis). Brain tissue was collected and tested for RABV antigen by the direct fluorescent antibody (DFA) test (Dean et al. 1996), using fluorescein isothiocyanate-labeled monoclonal antibody conjugate (Fujirebio Diagnostics, Inc., Malvern, Pennsylvania, USA). For all rabid bats, total RNA was extracted from individual brain tissues, and the RABV nucleoprotein gene was amplified and sequenced (Trimarchi and Smith 2002).

\section{Detection of RABV-neutralizing antibodies}

A modified rapid fluorescent focus inhibition test (Jackson et al. 2008), using RABV challenge virus standard (CVS-11), was used to assay for RABV-specific viral-neutralizing antibodies (RVNA) in the blood plasma of individual bats. Titers were calculated by the Reed-Muench method (Reed and Muench 1938), and values were converted to international units (IU/mL) by comparison to the US Standard Rabies Immune Globulin (Laboratory of Standards and Testing, Food and Drug Administration, Bethesda, Maryland, USA) diluted to $2 \mathrm{IU} / \mathrm{mL}$. The RVNA titers of individual bats were determined up to a level of $9.14 \mathrm{IU} / \mathrm{mL}$, equivalent to $50 \%$ neutralization at the eighth serial twofold dilution. The minimum level of RVNA detection in the modified rapid fluorescent focus inhibition test was defined as $\geq 0.06 \mathrm{IU} / \mathrm{mL}$, as reported previously (Turmelle et al. 2010). In this study, values $\geq 0.1 \mathrm{IU} / \mathrm{mL}$ were considered as evidence of neutralization, which was equivalent to a titer of about $1 / 22$. Titers at or above the cutoff of $0.1 \mathrm{IU} / \mathrm{mL}$ that exhibited a fourfold increase or greater above baseline values were considered as evidence of seroconversion PV or PI.

\section{Statistical analysis}

The RVNA titers that exceeded $9.14 \mathrm{IU} / \mathrm{mL}$ were coded as $9.14 \mathrm{IU} / \mathrm{mL}$ for the purpose of geometric mean calculations. Group geometric mean titers were calculated for different treatment groups, but they excluded bats that were seropositive upon baseline sampling as well as unvaccinated control bats in cage $\mathrm{U}$. The survival fraction and 95\% exact confidence interval (CI) were calculated among vaccine treatment and unvaccinated groups of RABV-challenged bats. A survival analysis was also performed among challenged bats to test for homogeneity in survival curves PI, using a log-rank test on data stratified by vaccine treatment and route and the Šidák correction to adjust for multiple pairwise comparisons. SAS version 9.4 was used to perform all analyses (SAS Institute, Cary, North Carolina, USA), and significance was assessed at $\alpha=0.05$.

\section{RESULTS}

In total, 57 individual big brown bats were included in the study (Table 1; Supplementary Material Table S1). Three bats (\#42, 54, 72) presented evidence of RVNA during baseline sampling and were treated as contact controls during experiment 1 (cage P). On day 98 PV of experiment 1 , they were kept in the same cage but challenged with RABV as part of experiment 2. Two other bats (\#31 and 33) were used as contact controls in separate cages during experiment 1 , but neither demonstrated evidence of RVNA during the study (Supplementary Material Table S1; serology data not shown). These bats were censored during experiment 1 on days 118 (\#31) and 161 (\#33) PV and were not used during experiment 2.

\section{Vaccination}

In the group of 25 bats vaccinated by IM route, three bats presented evidence of RVNA at baseline (\#10, 23, 29; Table 2). Among 22 bats vaccinated by IM route that were seronegative at baseline, a moderate propor- 
TABLE 1. Study design of two consecutive experiments to evaluate efficacy of intramuscular (IM) or oral (PO) delivery of ERA-g333 ${ }^{\text {a }}$ recombinant rabies virus vaccine to 57 big brown bats (Eptesicus fuscus).

\begin{tabular}{lllllll}
\hline Experiment & $\begin{array}{c}\text { No. } \\
\text { bats }\end{array}$ & \multicolumn{1}{c}{$\begin{array}{c}\text { Cage } \\
\text { ID }\end{array}$} & $\begin{array}{c}\text { Vaccine } \\
\text { routes }\end{array}$ & $\begin{array}{c}\text { Vaccination } \\
\text { date }\end{array}$ & $\begin{array}{c}\text { Infection date (day 21 } \\
\text { postvaccination) }\end{array}$ & $\begin{array}{c}\text { Experiment } \\
\text { end date }\end{array}$ \\
\hline 1 & 32 & L, M, N, O, P, Q & IM, PO & 18 July 2007 & 8 August 2007 & 26 December 2007 \\
2 & $25^{\mathrm{b}}$ & R, S, T, U, V & IM & 18 October 2007 & 8 November 2007 & 27 March 2008 \\
\hline
\end{tabular}

${ }^{a}$ ERA-g33 = Evelyn-Rokitniki-Abelseth (ERA) strain of rabies virus with three nucleotides altered at position 333 of the ERA glycoprotein gene.

${ }^{\mathrm{b}}$ Three contact control bats with preexisting rabies virus-neutralizing antibody titers were challenged with rabies virus together with other bats during experiment 2 , within their original cage $\mathrm{P}$, and are only included in the tally of experiment 1 bats.

Five control bats that were experimentally challenged with rabies virus and housed in cage $\mathrm{U}$ were excluded from the analysis due to an outbreak of a natural rabies virus infection within that cage.

tion had seroconverted by days 14-19 PV $(60 \%, 12 / 20$; Table 2), whereas evidence of seroconversion prior to challenge on day 21 PV could not be determined for two bats (\#15, 22 ). The RVNA geometric mean titers among the 22 bats that were seronegative at baseline and vaccinated by IM was $0.39 \mathrm{IU} / \mathrm{mL}$ on days 14-19 PV. Although eight bats did not seroconvert prior to challenge on day $21 \mathrm{PV}$ (\#12, 14, 19, 20, 25, 26, 39, 47), only two bats $(\# 19,25)$ remained seronegative PV until being censored from study on days 27 and 125 PV. Four (\#14, 38, 41, 51) IM vaccinates that were seronegative at baseline demonstrated RVNA as early as day $5 \mathrm{PV}$, suggestive of prior RABV exposure history. No RVNA were detected during the baseline sampling of 10 bats vaccinated by PO route, and none of these bats seroconverted during the study (Table 3). No adverse events related to vaccination were noted in any subjects (e.g., reversion to virulence). Only one bat of the unvaccinated control group demonstrated RVNA during baseline sampling (\#21, cage $\mathrm{U}$; Table 4) and prior to challenge.

\section{RABV challenge}

Two of the three bats $(\# 10,23)$ vaccinated by IM route and presenting RVNA upon baseline sampling were challenged, and both survived along with 18 bats vaccinated by IM route that were seronegative prior to vaccination (Table 5 and Fig. 1). All bats that were seronegative at baseline and vaccinated by IM route were protected against rabies infection
(17/17, 95\% CI 82-100), excluding one bat (\#19) censored on day 27 PV. Survival among bats vaccinated by PO route was $57 \%(4 / 7$, 95\% CI 25-84). Three bats vaccinated by PO route developed clinical rabies and were euthanized on days 24, 26, and 87 PI, respectively. Among unvaccinated controls, we retroactively diagnosed an outbreak of natural infection among bats in cage $\mathrm{U}$, and these five bats were excluded from the analysis (see Supplementary Material Table S2). The remaining 12 unvaccinated controls were seronegative during the study, except for one bat (\#35) that presented RVNA on day 6 PI, perhaps suggestive of a prior RABV exposure history. Survival among unvaccinated controls was $44 \%$ (4/9, 95\% CI 19-73) with a median incubation period of $26 \mathrm{~d}$ (range: 20-115 d), excluding two censored bats and one bat missing a diagnostic DFA result. The three seropositive contact controls from cage $\mathrm{P}$ survived RABV challenge during experiment 2, although there was equivocal evidence for a boosting effect of challenge on RVNA levels PI (Table 6). The IM vaccinate group had greater survival compared to both the PO vaccinate group $\left(\chi^{2}=8.5, P=0.01\right)$ and unvaccinated controls $\left(\chi^{2}=9.7, P=0.006\right)$, but there was no difference in survival between the PO vaccinates and unvaccinated controls $\left(\chi^{2}=0.5, P=0.86\right)$.

\section{Detection of naturally infected bats}

The first rabid bat from cage $\mathrm{U}$ (unvaccinated controls) was found dead in its cage on 
TABLE 2. Rabies virus-neutralizing antibody (IU/mL) detected in sera from 25 big brown bats (Eptesicus fuscus) vaccinated intramuscularly with $5 \times 10^{6}$ focus-forming units of ERA-g $333^{\text {a }}$ recombinant rabies virus vaccine (day $0)$. Twenty bats were challenged with $10^{2.9}$ mouse intracerebral median lethal dose $\left(\mathrm{MICLD}_{50}\right)$ of a big brown bat rabies virus on day 21 postvaccination (PV), and five bats were not challenged. All bats were observed for 140 d postinfection. Sampling time points are labeled by PV day. Where two values are listed, bats were sampled on different days between experiments.

\begin{tabular}{|c|c|c|c|c|c|c|c|c|c|}
\hline \multirow[b]{2}{*}{ Cage } & \multirow{2}{*}{$\begin{array}{l}\text { Challenge dose } \\
\left(\log \text { MICLD }_{50}\right)^{\mathrm{b}}\end{array}$} & \multirow{2}{*}{$\begin{array}{l}\text { Bat } \\
\text { ID }\end{array}$} & \multicolumn{7}{|c|}{$\begin{array}{l}\text { Rabies-neutralizing antibody }(\mathrm{IU} / \mathrm{mL}) \text { at days PV } \\
(\text { experiment 1/experiment } 2)^{\mathrm{c}}\end{array}$} \\
\hline & & & 0 & 5 & $14 / 19$ & $27 / 34$ & $43 / 49$ & $90 / 98$ & $155 / 161$ \\
\hline $\mathrm{L}$ & 2.9 & 39 & $<0.06$ & $<0.06$ & 0.09 & 0.06 & 0.72 & 0.91 & ND \\
\hline $\mathrm{L}$ & 2.9 & 496 & $<0.06$ & $<0.06$ & 1.62 & $>9.14$ & $>9.14$ & 5.08 & ND \\
\hline $\mathrm{L}$ & 2.9 & 47 & $<0.06$ & $<0.06$ & 0.14 & $<0.06$ & 0.19 & 0.06 & ND \\
\hline $\mathrm{L}$ & 2.9 & 48 & $<0.06$ & $<0.06$ & 1.42 & $<0.06$ & $<0.06$ & $<0.06$ & 0.19 \\
\hline M & 2.9 & 51 & $<0.06$ & 0.11 & 1.14 & 0.40 & 1.92 & 3.41 & 2.96 \\
\hline M & 2.9 & 55 & $<0.06$ & $<0.06$ & 3.29 & 0.57 & 1.14 & 2.10 & 3.25 \\
\hline M & 2.9 & 38 & $<0.06$ & 1.70 & $>9.14$ & $>9.14$ & $>9.14$ & 8.21 & ND \\
\hline M & 2.9 & 41 & $<0.06$ & 0.29 & 0.57 & 2.53 & 1.73 & 2.46 & 6.10 \\
\hline $\mathrm{R}$ & 2.9 & 66 & $<0.06$ & $<0.06$ & 0.40 & 0.64 & 1.48 & 1.34 & 0.07 \\
\hline $\mathrm{R}$ & 2.9 & 12 & $<0.06$ & $<0.06$ & 0.10 & $<0.06$ & $<0.06$ & 0.12 & $<0.06$ \\
\hline $\mathrm{R}$ & 2.9 & 19 & $<0.06$ & ND & $<0.06$ & & & & \\
\hline $\mathrm{R}$ & 2.9 & 26 & $<0.06$ & $<0.06$ & $<0.06$ & ND & ND & 1.14 & 0.42 \\
\hline S & 2.9 & 69 & $<0.06$ & $<0.06$ & 1.62 & 4.57 & 1.91 & 0.14 & $<0.06$ \\
\hline S & 2.9 & 10 & 0.21 & ND & 1.94 & 3.29 & 3.75 & 0.29 & 0.07 \\
\hline S & 2.9 & 20 & $<0.06$ & $<0.06$ & 0.08 & 0.10 & 0.14 & $<0.06$ & 0.09 \\
\hline S & 2.9 & 22 & $<0.06$ & $<0.06$ & ND & 0.29 & 0.32 & 0.08 & $<0.06$ \\
\hline V & 2.9 & 67 & $<0.06$ & $<0.06$ & 0.29 & 1.92 & 0.57 & 0.11 & 0.40 \\
\hline V & 2.9 & 14 & $<0.06$ & 0.11 & ND & ND & ND & ND & 0.30 \\
\hline V & 2.9 & 15 & $<0.06$ & $<0.06$ & ND & 0.26 & ND & 0.13 & 0.36 \\
\hline V & 2.9 & 23 & 0.87 & 0.29 & $>9.14$ & $>9.14$ & ND & 7.49 & \\
\hline $\mathrm{L}$ & NI & 45 & $<0.06$ & $<0.06$ & 6.27 & $<0.06$ & 0.82 & 0.09 & 0.20 \\
\hline M & NI & 50 & $<0.06$ & $<0.06$ & 0.51 & 0.87 & 0.10 & 0.20 & 0.08 \\
\hline $\mathrm{R}$ & NI & 28 & $<0.06$ & $<0.06$ & 0.33 & 0.11 & 0.42 & 0.12 & 0.20 \\
\hline S & NI & 29 & 0.52 & 0.19 & 0.47 & 0.85 & 0.24 & 0.43 & 0.22 \\
\hline V & NI & 25 & $<0.06$ & $<0.06$ & $<0.06$ & ND & ND & $<0.06$ & ND \\
\hline
\end{tabular}

${ }^{\text {a }}$ ERA-g33 = Evelyn-Rokitniki-Abelseth (ERA) strain of rabies virus with three nucleotides altered at position 333 of the ERA glycoprotein gene.

${ }^{\mathrm{b}} \mathrm{NI}=$ not infected.

${ }^{\mathrm{c}} \mathrm{ND}=$ not determined; insufficient blood sample from that bat-time point.

day 5 PI. Three additional bats in the cage subsequently developed signs of clinical rabies and were euthanized on days 50,61 , and $91 \mathrm{PI}$, respectively. The only bat in cage $\mathrm{U}$ that survived both the natural outbreak and experimental RABV challenge demonstrated a moderate level of RVNA (1.0 IU/ $\mathrm{mL}$; Table 4) during baseline sampling and remained seropositive at least until day 13 PI and tested DFA negative upon censoring on day 76 PI. Although all cage U bats were challenged experimentally with RABV, the four rabid bats in cage $\mathrm{U}$ were infected with a big brown bat RABV that typed as an eastern E. fuscus lineage (e1), along with the experimental RABV challenge inoculum, but the inoculum and outbreak viruses consistently differed by $1.2 \%$ across $1.35 \mathrm{~kb}$ of nucleoprotein sequence. Following demonstration of a different RABV variant infecting bats from this cage, we determined that bat \#65 had a minimum incubation period of $60 \mathrm{~d}$, considering the date of its intake from the wild. 
TABLE 3. Rabies virus-neutralizing antibody ( $\mathrm{IU} / \mathrm{mL}$ ) detected in sera from 10 big brown bats (Eptesicus fuscus) vaccinated orally with $5 \times 10^{6}$ focus-forming units of ERA-g $333^{\text {a }}$ recombinant rabies virus vaccine. Seven bats were challenged with $10^{2.9}$ mouse intracerebral median lethal dose $\left(\mathrm{MICLD}_{50}\right)$ of a big brown bat rabies virus on day 21 postvaccination (PV), and three bats were not challenged. All bats were observed for $140 \mathrm{~d}$ postinfection. Sampling time points are labeled by PV day. Where two values are listed, bats were sampled on different days between experiments.

\begin{tabular}{|c|c|c|c|c|c|c|c|c|c|}
\hline \multirow[b]{2}{*}{ Cage } & \multirow{2}{*}{$\begin{array}{l}\text { Challenge dose } \\
\left(\log \text { MICLD }_{50}\right)^{b}\end{array}$} & \multirow{2}{*}{$\begin{array}{l}\text { Bat } \\
\text { ID }\end{array}$} & \multicolumn{7}{|c|}{$\begin{array}{l}\text { Rabies-neutralizing antibody }(\mathrm{IU} / \mathrm{mL}) \text { at days } \mathrm{PV} \\
(\text { experiment 1/experiment } 2)^{\mathrm{c}}\end{array}$} \\
\hline & & & 0 & 5 & $14 / 19$ & $27 / 34$ & $43 / 49$ & $90 / 98$ & $155 / 161$ \\
\hline $\mathrm{N}$ & 2.9 & 500 & $<0.06$ & $<0.06$ & $<0.06$ & $<0.06$ & $<0.06$ & $<0.06$ & $<0.06$ \\
\hline $\mathrm{N}$ & 2.9 & 52 & $<0.06$ & $<0.06$ & $<0.06$ & $<0.06$ & ND & & \\
\hline $\mathrm{N}$ & 2.9 & 53 & $<0.06$ & $<0.06$ & $<0.06$ & $<0.06$ & $<0.06$ & $<0.06$ & $<0.06$ \\
\hline $\mathrm{N}$ & 2.9 & 59 & $<0.06$ & $<0.06$ & $<0.06$ & $<0.06$ & $<0.06$ & $<0.06$ & $<0.06$ \\
\hline $\mathrm{O}$ & 2.9 & 44 & $<0.06$ & $<0.06$ & $<0.06$ & $<0.06$ & $<0.06$ & & \\
\hline $\mathrm{O}$ & 2.9 & 43 & $<0.06$ & $<0.06$ & $<0.06$ & $<0.06$ & $<0.06$ & & \\
\hline $\mathrm{O}$ & 2.9 & 40 & $<0.06$ & $<0.06$ & $<0.06$ & $<0.06$ & $<0.06$ & $<0.06$ & $<0.06$ \\
\hline $\mathrm{O}$ & NI & 60 & $<0.06$ & $<0.06$ & ND & & & & \\
\hline $\mathrm{N}$ & NI & 463 & $<0.06$ & $<0.06$ & $<0.06$ & $<0.06$ & $<0.06$ & $<0.06$ & $<0.06$ \\
\hline $\mathrm{O}$ & NI & 61 & $<0.06$ & $<0.06$ & $<0.06$ & $<0.06$ & $<0.06$ & $<0.06$ & $<0.06$ \\
\hline
\end{tabular}

We report nine nonspecific deaths during this study: two euthanized due to poor acclimation (\#23, 25), one euthanized but missing a test result (i.e., unknown cause; \#24), three found dead from unknown causes $(\# 19,21,49)$, one bat that was injured (\#60), one bat that displayed clinical signs consistent with rabies but tested DFA negative (\#37), and one contact control bat that went missing (\#31). Other bats labeled as censored were uninfected controls that remained clinically normal during the observation period and were transferred to other studies; they were not tested for rabies during this study.

\section{DISCUSSION}

Although there are no efforts targeting control of insectivorous bat rabies in the Americas, the results of this study suggest that the ERA-g333 vaccine may be safe, immunogenic, and efficacious for big brown bats, and possibly other bats, such as the common vampire bat. While the PO dose of ERA-g333 tested in this study was neither immunogenic nor efficacious, it seems plausible that the dose may have been too low in comparison to the doses typically used for PO delivery to wild carnivores (Bankovskiy et al. 2008). In another rabies vaccination study involving big brown bats, immunogenicity and efficacy of a different live poxvirus vaccine construct by oronasal route occurred (Stading et al. 2017), and immunogenicity of a similar poxvirus construct was also demonstrated among Brazilian free-tailed bats (Tadarida brasiliensis) when delivered by oronasal route (Stading et al. 2016). We had low power to detect any difference in survivorship between PO vaccinates and controls, but the lack of RVNA responses among $\mathrm{PO}$ vaccinates during experiment 1 did not compel further replication of the treatment route during experiment 2. Future studies should consider PO testing of vaccine in bats at a dose more comparable to carnivores, although vaccine delivery volume constraints of working with some insectivorous bat species may require concentration of vaccine stock, as previously reported during a study with common vam- 
TABLE 4. Rabies virus-neutralizing antibody (IU/mL) detected in sera from 17 unvaccinated big brown bats

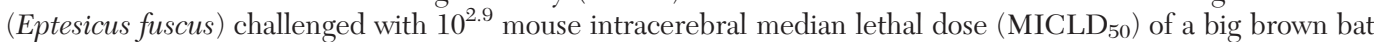
rabies virus on day 21 postvaccination (PV) and observed for 140 days postinfection. Sampling time points are labeled by PV day. Where two values are listed, bats were sampled on different days between experiments.

\begin{tabular}{|c|c|c|c|c|c|c|c|c|}
\hline \multirow[b]{2}{*}{ Cage } & \multirow{2}{*}{$\begin{array}{l}\text { Bat } \\
\text { ID }\end{array}$} & \multicolumn{7}{|c|}{$\begin{array}{l}\text { Rabies-neutralizing antibody }(\mathrm{IU} / \mathrm{mL}) \text { at days } \mathrm{PV} \\
(\text { experiment } 1 \text { /experiment } 2)^{\mathrm{a}}\end{array}$} \\
\hline & & 0 & 5 & $14 / 19$ & $27 / 34$ & $43 / 49$ & $90 / 98$ & $155 / 161$ \\
\hline $\mathrm{P}$ & 49 & $<0.06$ & $<0.06$ & $<0.06$ & $<0.06$ & $<0.06$ & $<0.06$ & \\
\hline $\mathrm{P}$ & 58 & $<0.06$ & ND & $<0.06$ & $<0.06$ & $<0.06$ & & \\
\hline $\mathrm{Q}$ & 32 & $<0.06$ & ND & $<0.06$ & $<0.06$ & & & \\
\hline Q & 34 & $<0.06$ & ND & $<0.06$ & $<0.06$ & $<0.06$ & & \\
\hline Q & 35 & $<0.06$ & ND & $<0.06$ & 0.13 & $<0.06$ & ND & ND \\
\hline Q & 36 & $<0.06$ & ND & $<0.06$ & $<0.06$ & $<0.06$ & $<0.06$ & $<0.06$ \\
\hline Q & 37 & $<0.06$ & ND & $<0.06$ & $<0.06$ & $<0.06$ & & \\
\hline $\mathrm{T}$ & 465 & $<0.06$ & $<0.06$ & $<0.06$ & $<0.06$ & $<0.06$ & $<0.06$ & ND \\
\hline $\mathrm{T}$ & 16 & $<0.06$ & $<0.06$ & $<0.06$ & $<0.06$ & $<0.06$ & & \\
\hline $\mathrm{T}$ & 18 & $<0.06$ & $<0.06$ & $<0.06$ & $<0.06$ & $<0.06$ & ND & $<0.06$ \\
\hline $\mathrm{T}$ & 24 & $<0.06$ & $<0.06$ & ND & ND & ND & & \\
\hline $\mathrm{T}$ & 27 & $<0.06$ & $<0.06$ & $<0.06$ & $<0.06$ & $<0.06$ & $<0.06$ & \\
\hline $\mathrm{U}$ & 65 & $<0.06$ & $<0.06$ & $<0.06$ & $<0.06$ & & & \\
\hline $\mathrm{U}$ & 11 & $<0.06$ & $<0.06$ & $<0.06$ & $<0.06$ & ND & & \\
\hline $\mathrm{U}$ & 17 & $<0.06$ & $<0.06$ & $<0.06$ & ND & $<0.06$ & $<0.06$ & \\
\hline $\mathrm{U}$ & 21 & 1.00 & 0.27 & 0.50 & 1.78 & ND & ND & \\
\hline $\mathrm{U}$ & 30 & $<0.06$ & $<0.06$ & ND & ND & ND & & \\
\hline
\end{tabular}

${ }^{\text {a }} \mathrm{ND}=$ not determined; insufficient blood sample from that bat-time point.

pire bats (Almeida et al. 2008). Similar to observations from experimental studies with common vampire bats and, more recently, insectivorous bats (Almeida et al. 2005, 2008; Stading et al. 2017), indirect routes of vaccination are also critical to evaluate once oral efficacy has been established, given the potential utility of social grooming oral contact behavior among gregarious bats to increase vaccination coverage beyond what can be achieved by direct delivery methods. Aerosol delivery may be another potential route for vaccinating wild bat populations, yet one study reported the immunogenicity, but not the efficacy, of an experimental aerosol vaccine delivery method (Davis et al. 2007). Our study suggests that live attenuated RABV constructs traditionally used for ORV of wild carnivores in North America and Europe may be efficacious for bats as well.

Other important insights regarding big brown bat RABV pathogenesis were made during the study. First, several of the bats that were collected from the wild presented RVNA during baseline sampling, which is consistent with observations of naturally occurring abortive RABV infections in sylvatic reservoirs and demonstrates that seronegative results do not necessarily imply a naïve exposure history among wild-caught mammals, as previously reported (Turmelle et al. 2010). Several others that were seronegative upon intake appeared to develop an anamnestic response to vaccination or challenge (i.e., RVNA seroconversion within 5-6 d PV or PI). The induction of a humoral antibody response to rabies vaccination typically takes 14-30 d to develop in response to a primary exposure. Rapid induction of the immune response within 5-6 d may be inconsistent with a primary exposure. Furthermore, naturally acquired RVNA (range: 0.2 to greater than $9.14 \mathrm{IU} / \mathrm{mL}$ ) was protective against RABV challenge in four bats. 
TABle 5. Survival outcomes among 39 big brown bats (Eptesicus fuscus) vaccinated with ERA-g333 recombinant rabies virus vaccine by the intramuscular (IM) or oral routes, or unvaccinated controls (NV). On day 21 postvaccination, all bats were experimentally challenged with $10^{2.9}$ mouse intracerebral median lethal dose $\left(\right.$ MICLD $\left._{50}\right)$ of a big brown bat rabies virus.

\begin{tabular}{|c|c|c|c|c|}
\hline Experiment & Cage & Bat ID & Vaccination route & Final disposition ${ }^{\mathrm{b}}$ \\
\hline 1 & $\mathrm{~L}$ & 39 & IM & $\mathrm{S}$ \\
\hline 1 & $\mathrm{~L}$ & 496 & $\mathrm{IM}$ & $\mathrm{S}$ \\
\hline 1 & $\mathrm{~L}$ & 47 & IM & $\mathrm{S}$ \\
\hline 1 & $\mathrm{~L}$ & 48 & IM & S \\
\hline 1 & M & 51 & IM & $\mathrm{S}$ \\
\hline 1 & M & 55 & IM & S \\
\hline 1 & M & 38 & IM & S \\
\hline 1 & M & 41 & IM & S \\
\hline 2 & $\mathrm{R}$ & 66 & IM & $\mathrm{S}$ \\
\hline 2 & $\mathrm{R}$ & 12 & IM & S \\
\hline 2 & $\mathrm{R}$ & 19 & IM & $\mathrm{N}$ \\
\hline 2 & $\mathrm{R}$ & 26 & IM & S \\
\hline 2 & $\mathrm{~S}$ & 69 & IM & $\mathrm{S}$ \\
\hline 2 & $\mathrm{~S}$ & 10 & IM & S \\
\hline 2 & $\mathrm{~S}$ & 20 & IM & S \\
\hline 2 & $\mathrm{~S}$ & 22 & IM & $\mathrm{S}$ \\
\hline 2 & $\mathrm{~V}$ & 67 & IM & $\mathrm{S}$ \\
\hline 2 & $\mathrm{~V}$ & 14 & $\mathrm{IM}$ & S \\
\hline 2 & $\mathrm{~V}$ & 15 & IM & S \\
\hline 2 & $\mathrm{~V}$ & 23 & IM & $\mathrm{N}$ \\
\hline 1 & $\mathrm{~N}$ & 500 & Oral & $\mathrm{S}$ \\
\hline 1 & $\mathrm{~N}$ & 52 & Oral & $\mathrm{D}(24)$ \\
\hline 1 & $\mathrm{~N}$ & 53 & Oral & S \\
\hline 1 & $\mathrm{~N}$ & 59 & Oral & S \\
\hline 1 & $\mathrm{O}$ & 44 & Oral & $\mathrm{D}(87)$ \\
\hline 1 & $\mathrm{O}$ & 43 & Oral & $\mathrm{D}(26)$ \\
\hline 1 & $\mathrm{O}$ & 40 & Oral & S \\
\hline 1 & $\mathrm{P}$ & 49 & $\mathrm{NV}$ & $\mathrm{N}$ \\
\hline 1 & $\mathrm{P}$ & 58 & $\mathrm{NV}$ & $\mathrm{D}(26)$ \\
\hline 1 & $Q$ & 32 & $\mathrm{NV}$ & $\mathrm{D}(20)$ \\
\hline 1 & $\mathrm{Q}$ & 34 & $\mathrm{NV}$ & $\mathrm{D}(26)$ \\
\hline 1 & $\mathrm{Q}$ & 35 & $\mathrm{NV}$ & S \\
\hline 1 & $Q$ & 36 & $\mathrm{NV}$ & $\mathrm{S}$ \\
\hline 1 & $Q$ & 37 & $\mathrm{NV}$ & $\mathrm{N}$ \\
\hline 2 & $\mathrm{~T}$ & 465 & $\mathrm{NV}$ & $\mathrm{S}$ \\
\hline 2 & $\mathrm{~T}$ & 16 & $\mathrm{NV}$ & $\mathrm{D}(38)$ \\
\hline 2 & $\mathrm{~T}$ & 18 & $\mathrm{NV}$ & $\mathrm{S}$ \\
\hline 2 & $\mathrm{~T}$ & 24 & $\mathrm{NV}$ & ND \\
\hline 2 & $\mathrm{~T}$ & 27 & $\mathrm{NV}$ & $\mathrm{D}(115)$ \\
\hline
\end{tabular}

${ }^{a}$ ERA-g33 = Evelyn-Rokitniki-Abelseth (ERA) strain of rabies virus with three nucleotides altered at position 333 of the ERA glycoprotein gene.

${ }^{\mathrm{b}} \mathrm{S}=$ survived to $140 \mathrm{~d}$ postinfection and tested negative for rabies virus infection; $\mathrm{N}=$ tested negative for rabies virus infection (censored); $\mathrm{D}=$ died from infection with rabies virus, with incubation period in parentheses; ND = not determined, missing laboratory result for bat that was censored on day 51 postinfection. 


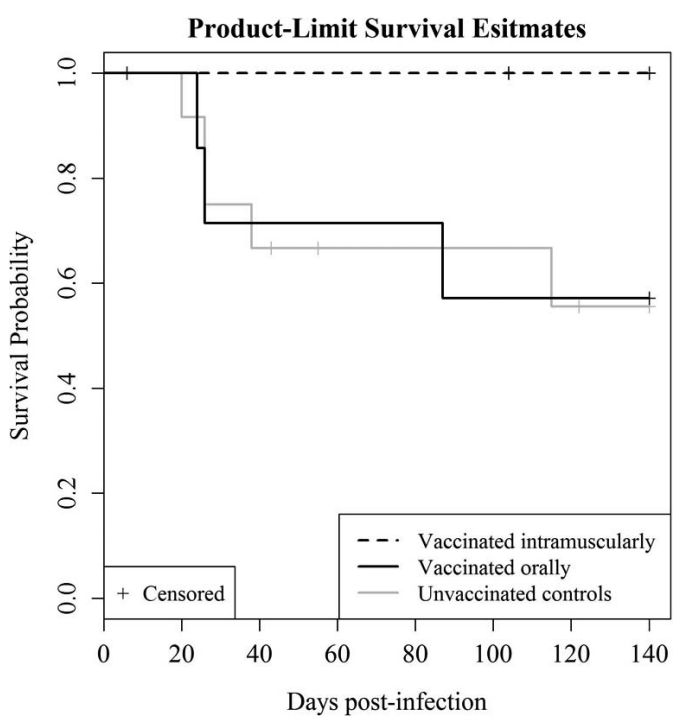

FIgURE 1. Survival probabilities for vaccinated and unvaccinated big brown bats (Eptesicus fuscus) experimentally challenged with rabies virus on day 21 postvaccination and observed for $140 \mathrm{~d}$ postinfection.

Bats may be incubating RABV infection upon collection from the wild, with potential for bat-to-bat transmission in captive settings and safety risks to humans and animals (Shankar et al. 2004; Davis et al. 2012). While we cannot conclusively establish that natural RABV transmission occurred during our study, it seems more parsimonious in comparison to a hypothesis of independent incubation of RABV infections in four bats in a single cage. The outbreak in this study was associated with an autumn collection of big brown bats, a time of year where population infection prevalence may be elevated (George et al. 2011).

In conclusion, IM delivery of the ERA-g333 live attenuated recombinant RABV vaccine was safe, immunogenic, and efficacious in protecting big brown bats against a lethal challenge, yet PO delivery was neither immunogenic nor efficacious. However, it remains possible that a higher vaccine dose by the PO route may be effective. While broad-scale delivery of vaccines to wild bats still presents logistical challenges, additional studies testing oral rabies vaccines in insectivorous and other bats are warranted, particularly for key RABV reservoir hosts.

\section{ACKNOWLEDGMENTS}

This study was supported in part by a National Science Foundation-National Institutes of Health Ecology of Infectious Disease grant (0430418 to G.F.M.) and an Environmental Protection Agency Science-to-Achieve-Results Fellowship to A.T.G. The authors thank staff on the Rabies Team at the Centers for Disease Control and Prevention and the Animal Resources Branch in Lawrenceville, Georgia, for their expertise. Special thanks also go to I. Kuzmin, B. Panasuk, C. Horner, and D.

TABLE 6. Rabies virus-neutralizing antibody (IU/mL) detected in sera from three unvaccinated and seropositive big brown bats (Eptesicus fuscus), all held in cage $\mathrm{P}$ and treated as contact controls during experiment 1 . These bats were experimentally challenged with $10^{2.9}$ mouse intracerebral median lethal dose (MICLD 50 ) of a big brown bat rabies virus on the same day as the experiment 2 bats and were observed for $140 \mathrm{~d}$ postinfection. Where two values are listed, bats were sampled on different days between experiments.

\begin{tabular}{lccccccccc}
\hline & & \multicolumn{7}{c}{ Rabies-neutralizing antibody (IU/mL) at days postvaccination } \\
(experiment 1/experiment 2)
\end{tabular}


Green for technical assistance during the study. Use of trade names and commercial sources are for identification only and do not imply endorsement by the US Department of Health and Human Services. The findings and conclusions in this report are those of the authors and do not necessarily represent the official position of the Centers for Disease Control and Prevention.

\section{SUPPLEMENTARY MATERIAL}

Supplementary material for this article is online at http://dx.doi.org/10.7589/2019-04-108.

\section{LITERATURE CITED}

Almeida MF, Martorelli LF, Aires CC, Barros RF, Massad E. 2008. Vaccinating the vampire bat Desmodus rotundus against rabies. Virus Res 137: 275-277.

Almeida MF, Martorelli LF, Aires CC, Sallum PC, Massad E. 2005. Indirect oral immunization of captive vampires, Desmodus rotundus. Virus Res 111:77-82.

Bankovskiy D, Safonov G, Kurilchuk Y. 2008. Immunogenicity of the ERA G 333 rabies virus strain in foxes and raccoon dogs. Dev Biol 131:461-466.

Davis A, Gordy P, Rudd R, Jarvis JA, Bowen RA. 2012. Naturally acquired rabies virus infections in wildcaught bats. Vector Borne Zoonotic Dis 12:55-60.

Davis AD, Rudd RJ, Bowen RA. 2007. Effects of aerosolized rabies virus exposure on bats and mice. J Infect Dis 195:1144-1150.

De Serres G, Dallaire F, Côte M, Skowronski DM. 2008. Bat rabies in the United States and Canada from 1950 through 2007: Human cases with and without bat contact. Clin Infect Dis 46:1329-1337.

Dean DJ, Abelseth MK, Atanasiu P. 1996. The fluorescent antibody test. In: Laboratory techniques in rabies, Meslin FX, Kaplan MM, Koprowski H, editors. World Health Organization, Geneva, Switzerland, pp. 88-93.

Dietzschold B, Wunner WH, Wiktor TJ, Lopes AD, Lafon M, Smith CL, Koprowski H. 1983. Characterization of an antigenic determinant of the glycoprotein that correlates with pathogenicity of rabies virus. Proc Natl Acad Sci U S A 80:70-74.

Fehlner-Gardiner C, Nadin-Davis S, Armstrong J, Muldoon F, Bachmann P, Wandeler A. 2008. ERA vaccine-derived cases of rabies in wildlife and domestic animals in Ontario, Canada, 1989-2004. J Wildl Dis 44:71-85.

Franka R, Wu X, Jackson FR, Velasco-Villa A, Palmer DP, Henderson H, Hayat W, Green DB, Blanton JD, Greenberg L, et al. 2009. Rabies virus pathogenesis in relationship to intervention with inactivated and attenuated rabies vaccines. Vaccine 27:7149-7155.

George DB, Webb CT, Farnsworth ML, O'Shea TJ, Bowen RA, Smith DL, Stanley TR, Ellison LE,
Rupprecht CE. 2011. Host and viral ecology determine bat rabies seasonality and maintenance. Proc Natl Acad Sci U S A 108:10208-10213.

Gilbert AT. 2018. Rabies virus vectors and reservoir species. Rev Sci Tech 37:371-384.

Hampson K, Coudeville L, Lembo T, Sambo M, Kieffer A, Attlan M, Barrat J, Blanton JD, Briggs DJ, Cleaveland S, et al. 2015. Estimating the global burden of endemic canine rabies. PLoS Negl Trop Dis 9:e0003709.

Jackson FR, Turmelle AS, Farino DM, Franka R, McCracken GF, Rupprecht CE. 2008. Experimental rabies virus infection of big brown bats (Eptesicus fuscus). J Wildl Dis 44:612-621.

Kuzmin IV, Shi M, Orciari LA, Yager PA, Velasco-Villa A, Kuzmina NA, Streicker DG, Bergman DL, Rupprecht CE. 2012. Molecular inferences suggest multiple host shifts of rabies viruses from bats to mesocarnivores in Arizona during 2001-2009. PLoS Pathog 8:e1002786.

Lafay F, Benejean J, Tuffereau C, Flamand A, Coulon P. 1994. Vaccination against rabies: Construction and characterization of SAG2, a double avirulent derivative of SAD Bern. Vaccine 12:317-320.

Le Blois H, Tuffereau C, Blancou J, Artois M, Aubert A, Flamand A. 1990. Oral immunization of foxes with avirulent rabies virus mutants. Vet Microbiol 23:259 266.

Leslie MJ, Messenger S, Rohde RE, Smith J, Cheshier R, Hanlon C, Rupprecht CE. 2006. Bat-associated rabies virus in skunks. Emerg Infect Dis 12:12741277.

MacInnes CD, Smith SM, Tinline RR, Ayers NR, Bachmann P, Ball DG, Calder LA, Crosgrey SJ, Fielding C, Hauschildt P, et al. 2001. Elimination of rabies from red foxes in eastern Ontario. $J$ Wildl Dis 37:119-132.

Mähl P, Cliquet F, Guiot AL, Niin E, Fournials E, SaintJean N, Aubert M, Rupprecht CE, Gueguen S. 2014. Twenty year experience of the oral rabies vaccine SAG2 in wildlife: A global review. Vet Res 45:77.

Messenger SL, Smith JS, Rupprecht CE. 2002. Emerging epidemiology of bat-associated cryptic cases of rabies in humans in the United States. Clin Infect Dis 35: 738-747.

Muller T, Freuling CM, Wysocki P, Roumiantzeff M, Freney J, Mettenleiter TC, Vos A. 2015. Terrestrial rabies control in the European Union: Historical achievements and challenges ahead. Vet J 203:10-17.

Reed LJ, Muench H. 1938. A simple method of estimating fifty percent endpoints. Am J Hyg 27:493-497.

Schneider MC, Romijn PC, Uieda W, Tamayo H, Da Silva DF, Belotto A, Da Silva JB, Leanes LF. 2009. Rabies transmitted by vampire bats to humans: An emerging zoonotic disease in Latin America? Rev Panam Salud Publica 25:260-269.

Shankar V, Bowen RA, Davis AD, Rupprecht CE, O'Shea TJ. 2004. Rabies in a captive colony of big brown bats (Eptesicus fuscus). J Wildl Dis 40:403-413. 
Smith TG, Wu X, Ellison JA, Wadhwa A, Franka R, Langham GL, Skinner BL, Hanlon CA, Bronshtein VL. 2017. Assessment of the immunogenicity of rabies vaccine preserved by vaporization and delivered to the duodenal mucosa of gray foxes (Urocyon cinereoargenteus). Am J Vet Res 78:752-756.

Stading B, Ellison JA, Carson WC, Satheshkumar PS, Rocke TE, Osorio JE. 2017. Protection of bats (Eptesicus fuscus) against rabies following topical or oronasal exposure to a recombinant raccoon poxvirus vaccine. PLoS Negl Trop Dis 11:e0005958.

Stading BR, Osorio JE, Velasco-Villa A, Smotherman M, Kingstad-Bakke B, Rocke TE. 2016. Infectivity of attenuated poxvirus vaccine vectors and immunogenicity of a raccoonpox vectored rabies vaccine in the Brazilian free-tailed bat (Tadarida brasiliensis). Vaccine 34:5352-5358.

Trimarchi CV, Smith J. 2002. Diagnostic evaluation. In: Rabies, Jackson AC, Wunner WH, editors. Academic Press, San Diego, California, pp. 308-344.

Turmelle AS, Jackson FR, Green D, McCracken GF, Rupprecht CE. 2010. Host immunity to repeated rabies virus infection in big brown bats. J Gen Virol 91:2360-2366

Voigt CC, Cruz-Neto A. 2009. Energetic analysis of bats. In: Ecological and behavioral methods for the study of bats, Kunz TH, Parsons S, editors. The Johns Hopkins University Press, Baltimore, Maryland, pp. 623-645.
Vuta V, Picard-Meyer E, Robardet E, Barboi G, Motiu R, Barbuceanu F, Vlagioiu C, Cliquet F. 2016. Vaccineinduced rabies case in a cow (Bos taurus): Molecular characterisation of vaccine strain in brain tissue. Vaccine 34:5021-5025.

World Health Organization (WHO). 2018. WHO expert consultation on rabies, third report. WHO Technical Report Series 1012. WHO, Geneva, Switzerland, 183 pp.

Wu X, Franka R, Henderson H, Rupprecht CE. 2011. Live attenuated rabies virus co-infected with street rabies virus protects animals against rabies. Vaccine 29:4195-4201.

Yang DK, Kim HH, Choi SS, Kim JT, Lee KB, Lee SH, Cho IS. 2016. Safety and immunogenicity of recombinant rabies virus (ERAGS) in mice and raccoon dogs. Clin Exp Vaccine Res 5:159-168.

Yang DK, Kim HH, Jo HY, Kim HW, Choi SS, Cho IS. 2015. Safety and immunogenicity of a recombinant rabies virus strain (ERAG3G) in Korean raccoon dogs. J Bacteriol Virol 45:250-255.

Yang DK, Nakagawa K, Ito N, Kim HH, Hyun BH, Nah JJ, Sugiyama M, Song JY. 2014. A single immunization with recombinant rabies virus (ERAG3G) confers complete protection against rabies in mice. Clin Exp Vaccine Res 3:176-184.

Submitted for publication 29 April 2019.

Accepted 9 October 2019 